\title{
PENDIDIKAN KEAKSARAAN DALAM PERSFEKTIF PSIKOLOGI SOSIAL
}

\section{Abstrak}

Jumlah kelompok buta aksara masih cukup signifikan. Ini adalah tantangan pendidikan nasional, apalagi melek huruf menjadi salah satu indikator Human Developmen Indek (HDI). Psikologi sosial yang dapat menjelaskan perilaku individu dan konteks sosial sangat diperlukan dalam proses pendidikan keaksaraan. Karakter utama kelompok buta aksara adalah orang dewasa dan miskin. Langkah awal pendidikan keaksaraan adalah membangkitkan motivasi mereka melalui materi yang bisa meningkatkan pendapatan dan kecakapan real hidup mereka. Selanjutnya dapat dibangun persepsi, motif, sikap, dan perilaku positif tentang pentingnya melek huruf di era global ini. Di sisi lain nilai-nilai empati, tanggungjawab sosial, atau norma keseimbangan bagi warga negara berkecukupan perlu dikembangkan kepada kelompok ini. Oleh karena itu pendidikan keaksaraan perlu ditangani secara terpadu dengan melibatkan pihak terkait.

Kata Kunci: Pendidikan keaksaraan, melek huruf, baca, tulis, berhitung

\section{A. PENDAHULUAN}

Abad 21 adalah fase masyarakat informasi. Masyarakat informasi ditandai adanya terpaan (exposure) media massa dan komunikasi global, masyarakat yang sadar informasi, mendapatkan penerangan cukup, serta ditunjang oleh prasarana jalan raya informasi dan dukungan teknologi (Alwi Dahlan, 1997). Di massa

*) Ir. Yuni Sugiarti, adalah dosen Institut Teknologi Indonesia 
informasi ini dunia seolah sempit, komunikasi dan informasi di berbagai belahan dunia bisa diikuti dengan begitu cepat. Namun sungguh ironis, dalam fase masyarakat informasi ini masih banyak kelompok masyarakat yang buta aksara atau belum bisa membaca, menulis, dan berhitung.

Tahun 2003 penduduk Indonesia yang masih buta aksara usia 15 tahun ke atas mencapai 15,4 juta jiwa atau sekitar 9,5\% dari jumlah penduduk. Jumlah ini $81,26 \%$ ada di 9 propinsi yaitu Banten, Jawa Barat, Jawa Tengah, Jawa Timur, NTT, NTB, Kalimantan Barat, Sulawesi Selatan, dan Papua (BPS, 2004).

Masalah buta aksara tidak hanya terjadi di Indonesia. Di banyak negara terutama di negara-negara Asia Pasifik jumlah buta aksara masih relatif tinggi. Tingginya angka ini mempunyai kecendrungan tingkat sosial ekonomi yang rendah. Demikian juga anggota masyarakat yang buta aksara sering tersisihkan (kelompok marginal) dalam proses pembangunan terutama memperoleh informasi, kegiatan ekonomi dan politik.

Secara nasional pemberantasan buta aksara mempunyai nilai yang sangat strategis. Dunia internasional memasukan salah alat ukur indeks pembangunan manusia atau Human Development Index (HDI) adalah masalah buta aksara penduduk. Kenyataanya HDI Indonesia masih rendah bahkan dibawah negara-negara Asean lainya.

Menyadari hal tersebut pemerintah (Depdiknas) konsen memberantas buta aksara melalui program Pendidikan Keaksaraan melalui jalur pendidikan non formal. Hal ini sesuai dengan amanat UUD 1945 pasal 31 yang menegaskan bahwa "Setiap warga negara mempunyai hak untuk memperoleh pengajaran". Ini berarti setiap warga negara tanpa pandang umur atau golongan berhak memperoleh pendidikan untuk dapat mengembangkan diri sesuai potensinya masing-masing. 
Pendidikan keaksaraan dalam kerangka pendidikan non formal tidak lepas dari aspek sosial. Kondisi ini menjadi menarik untuk dikaji lebih jauh dari aspek psikologi sosial. Tulisan ini akan mencoba mengkaji tentang peran psikologi sosial dalam pendidikan keaksaraan, Faktor-faktor yang menjadikan penyebab terjadinya buta aksara, karakteristik kelompok buta aksara, serta model pendidikan keaksaraan yang dapat dikembangkan dalam persfektif psikologi sosial.

\section{B. KAJIAN LITERATUR DAN PEMBAHASAN}

\section{Psikologi Sosial Pendidikan Non Formal}

Banyak pakar psikologi yang memberikan definisi tentang psikologi sosial berdasarkan sudut pandang dan penekanannya. Prinsipnya psikologi sosial diartikan sebagai ilmu pengetahuan yang membahas perilaku individu dalam konteks sosial (Sarwono, 2002). Definisi ini mengandung dua unsur pokok yaitu perilaku individu dan konteks sosial. Jadi psikologi sosial tidak hanya mempelajari perilaku dalam konteks individu, tetapi juga interaksi individu dengan kelompok, dan kelompok dengan kelompok.

Hakekat pendidikan terutama dalam pendidikan non formal adalah kegiatan mendidik orang (proses pendidikan) dengan tujuan mengubah perilaku sasaran sesuai dengan yang direncanakan/dikehendaki. Ini menunjukan bahwa inti dari pendidikan adalah mengubah perilaku manusia, sehingga mau meninggalkan perilaku lama yang tidak sesuai dengan tuntutan kebutuhan hidupnya dan menggantikannya dengan perilaku yang lebih baik.

Upaya mengubah perilaku ini tentu saja diperlukan disiplin ilmu psikologi dalam hal ini psikologi sosial dalam menjelaskan perilaku manusia dalam konteks sosial. Di sisi lain 
kecenderungan masyarakat terus berkembang/berubah. Ada pepatah yang mengatakan bahwa di dunia ini tidak ada yang abadi, yang abadi adalah perubahan. Pemahaman tentang perilaku sosial, persepsi, diri pribadi dan sosial, perilaku antar pribadi, konflik, kompetisi, sikap, perilaku kelompok dan aspek sosial lainnya menjadi penting.

\section{Pendidikan Keaksaraan dalam Pembangunan}

Seberapa pentingkah pendidikan keaksaraan dalam pembangunan manusia Indonesia. Beberapa hasil studi menunjukan bahwa program pemberantasan buta aksara tidak lagi dipandang sebagai suatu bentuk pemborosan, tetapi sebagai sebuah investasi sumber daya manusia yang mempengaruhi aspek-aspek lainnya, seperti ekonomi, politik, sosial, budaya, dan sebagainya (Arif, 2000). Dalam studi lain Arif (1994) menunjukann bahwa petani yang melek huruf akan mudah merespon terhadap inovasi baru dalam bidang pertanian.

Studi lain dilakukan para ahli seperti Fisher (1982) menunjukan bahwa negara yang memiliki tingkat kemelekhurupannya tinggi berkorelasi positif dengan usia harapan hidup, tingkat partisifasi sekolah, serta tingkat kesadaran gizi dan kesehatan. Begitu pula hasil penelitian Anderson (1972) menunjukan bahwa tingkat kemelekhurufan berkorelasi positif dengan partisifasi anak-anak di sekolah, keberhasilan program imunisasi, dan respon petani terhadap usaha tani maju. Bahkan WHO (1992) menekankan bahwa pemberantasan buta aksara harus menjadi bagian yang terintegrasi dalam reformasi ekonomi. Ini disebabkan karena kebutaaksaraan dapat menimbulkan efek negatif terhadap generasi kedua.

Pentingnya penyuluhan keaksaraan ini telah diakui dunia, misalnya koperensi di Jomtien Thailand tahun 1990 yang didukung oleh Unesco, Unicef, World Bank, UNDP, dan UNFPA. Konferensi ini menyepakati "World Declaration on Education 
for All and the Framework for Acrtion to Meet Basic Learning Needs. Salah satu bentuk kebutuhan belajar dasar itu adalah pemberian pendidikan keaksaraan kepada seluruh warga negara yang karena berbagai hal, tidak dapat mengikuti pendidikan formal (Kusnadi, 2004).

Secara politis, setiap upaya pelayanan pendidikan kekasaraan, pada hakekatnya merupakan upaya mendidik rakyat agar mereka lebih bertanggungjawab, mudah memahami keinginan pemerintah dan menjidi warga negara yang produktif (Napitupulu, 1999). Dengan kata lain, upaya pendidikan keaksaraan adalah untuk menumbuhkan dan mendorong kelompok-kelompok marginal agar lebih aktif terlibat dalam proses pembangunan.

Inti pemikiran di atas bertitik tolak dari teori Marginal (Anany, 1980) yang beranggapan bahwa kelompok-kelompok masyarakat yang belum memperoleh pelayanan pendidikan keaksaraan akan kurang mampu berpartisifasi dalam proses politik, ekonomi, dan proses produksi. Agar mereka mampu melakukan perannya sebagai warga negara, maka kepada mereka perlu diberikan pelayanan pendidikan keaksaraan, sehingga mereka menjadi warga negara yang fungsional dalam proses politik dan ekonomi.

Pelayanan pendidikan keaksaraan akan memungkinkan kelompok-kelompok marginal yang ada di daerah perkotaan dan pedesaan mempunyai peluang untuk menguasai kemampuan dalam tiga hal (1) pengetahuan dan keterampilan berkomunikasi, (2) pengetahuan dan keterampilan belajar untuk hidup, (3) pengetahuan dan keterampilan berproduksi (Kusnadi, 2004).. Ketiga hal utama ini merupakan prasarat masyarakat era informasi dewasa ini.

\section{Penyebab dan Karakteristik Buta Aksara}


Secara umum buta aksara disebabkan oleh faktor struktural dan non struktural. Faktor struktural ini disebabkan oleh faktor lingkungan dan budaya. Suku-suku terasing yang hidup di lingkungan terisolir dan budaya yang tidak berorientasi ke depan. Suku seperti ini hidup di tengah hutan, pedalaman, pegunungan yang sulit dijangkau transportasi. Begitupun program penyuluhan kekasaraan baik dari pemerintah maupun swasta (LSM) sulit terjangkau. Akibatnya mereka buta aksara yang disebabkan struktur lingkungan yang tidak kondusif.

Faktor non struktural adalah berhubungan dengan kemiskinan yang biasanya terjadi dalam kelompok marginal. Kelompok ini hidupnya disibukan untuk mencari kebutuhan primer, seperti makan dan pakaian tanpa mempunyai kesempatan untuk mengikuti pendidikan keaksaraan. Faktor lainnya adalah karena krisis, rawan konflik, keterbatasan dana, kemapuan politik dan faktor lainnya, sehingga program keaksaraan tidak mampu menjaaangkau kelompok tersebut.

Menurut hasil penelitian UNESCO (dalam Kusnadi, 2004), beberapa indikator umum terjadinya kelompok buta aksara, antara lain:

a. Pada kebanyakan kelompok perempuan jumlah buta aksara umumnya lebih besar dibandingkan dengan kelompok laki-laki, data menunjukan dari 15,5 juta orang penduduk buta aksara usia 10 tahun ke atas, dan 3,9 juta orang berusia 15 s.d. 44 tahun, dimana 67,07\%-nya adalah perempuan.

b. Jumlah buta aksara terdapat di kalangan suku terasing atau kelompok-kelompok minoritas, yang kurang memiliki pada dunia pendidikan.

c. Di daerah perkotaan, jumlah buta aksara banyak terkosentrasi di daerah kawasan kumuh (slum area) yang penghuninya berpenghasilan rendah. Karena rendahnya pendapatan tersebut, mereka lebih mementingkan 'perut' daripada belajar. Akibatnya penghasilan rendah itu mereka 
tidak memiliki kemampuan membiayai pendidikan sendiri, apalagi membiayai pendidikan anak-anaknya, minimal tamat sekolah dasar.

d. Di daerah pedesaan, jumlah buta aksara banyak terkonsentrasi di daerah terpencil dengan tingfkat pendapatan penduduknya rendah.

e. Daerah yang tingkat partisakasi sekolah dasarnya rendah, maka jumlah buta aksara akan tinggi.

f. Daerah yang putus sekolah dasarnya pada kelas awal-awal tinggi, maka jumlah buta aksara akan tinggi pula.

Uraian di atas menunjukan bahwa buta aksara disebabkan oleh faktor kemiskinan, ketidakberdayaan ekonomi sehingga sulit untuk bisa sekolah atau mengikuti pendidikan keaksaraan. Faktor-faktor lain yang diasumsikan memicu kelompok buta aksara adalah faktor budaya, lokasi terpencil, kekurangan sarana, atau kebijakan pemerintah menambah tingginya angka buta aksara. Sementara itu dari karakteristiknya diketahui bahwa kelompok buta aksara adalah: orang dewasa, miskin, sebagian besar perempuan, serta tinggal di daerah pedesaan atau pinggiran kota di daerah kumuh.

\section{Model Pendidikan Keaksaraan}

\section{a. Membangkitkan motivasi}

Telah diuraikan di atas bahwa ekonomi merupakan penyebab utama buta aksara adalah ketidakberdayaan ekonomi. Jika dikaji lebih mendalam tentang penyebab kemiskinan, teori-teori psikologi sosial cenderung sejalan dengan pemikiran Antropolog Oscar Lewis tentang kemiskinan struktural. Konsep tersebut pada dasarnya menyebutkan bahwa kemiskinan berkaitan erat dengan faktor psikologis seperti malas dan kurang kreatif. Namun pada sisi lain psikologi sosial menempatkan pentingnya pemberdayan manusia agar mereka dapat lepas dari kemiskinan (Faturochman, 2006). 
Kemiskina tidak hanya karena malas, boros, atau nasibnya sial. Mereka miskin karena pengaruh struktur ekonomi, politik, dan sosial yang tidak adil. Keberpihakan kebijakan kepada kaum lemah masih kurang. Kaum petani misalnya, menurut pengamatan penulis, mereka seringkali mengalami kerugian. Hasil panen hanya bisa untuk menutupi biaya produksi; pupuk, upah kerja, dan bibit. Itupun jika tanamannya tidak kena hama penyakit. Jika itu terjadi malahan buntung yang diperoleh. Kondisi ini menunjukan bagaimana mereka bisa menyekolahkan anak, untuk mencukupi kebutuhan hidup saja susah.

Masyarakat kumuh di pinggiran kota yang disinyalir sebagai kantong kelompok buta aksara, umumnya memiliki kebutuhan hidup yang relatif tinggi. Sebgai konsekuensi kehidupan perkotaan. Mereka terjebak untuk mencukupi kebutuhan hidup. Anak-anaknya yang seharusnya sekolah dengan terpaksa membantu orangtua mencari nafkah. Akibatnya anak-anak mereka tumbuh berkembang hingga dewasa tanpa melek huruf.

Proses pendidikan keaksaraan dalam kelompok ini tidaklah mudah. Sulit rasanya jika pada mereka langsung diajak belajar membaca, menulis, atau berhitung. Di sini perlu dibangkitkan motivasinya. Ahmadi (1991) menjelaskan bahwa motivasi berkaitan dengan kebutuhan. Kebutuhan mereka adalah kebutuhan primer. Jadi perlu diupayakan pendidikan yang bisa meningkatkan pendapatan dalam mencukupi kebutuhan primer mereka. Melalui upaya ini diharapkan motivasi mereka bisa tumbuh. Jika motivasi telah terbangun diharapkan persepsi, sikap, dan perilakunya akan berubah terhadap perlunya kemampuan keaksaraan. Mereka didorong untuk memiliki kesadaran akan perlunya melek huruf sebagai modal dasar hidup di era informasi ini. 
b. Nilai empati, tanggungjawab sosial, dan keseimbangan Telah diuraikan di atas bahwa pendidikan keaksaraan dengan sasaran orang dewasa ini tidak cukup dengan mengajak mereka membaca, menulis dan juga berhitung. Mereka perlu dibekali ilmu pengetahuan, sikap, dan keterampilan dalam berbisnis. Di sini barangkali tidak cukup hanya dengan memberikan keterampilan tertentu, apalagi keterampilan itu sederhana yang sulit bersaing. Mereka juga perlu dibekali dengan manajemen usaha, manajemen pemasaran hasil produksi, termasuk pendampingan usaha dengan melibatkan penguasah swasta. Di sinilah masalah perlunya ditanamkan tolong menolong antar sesama manusia. Permasalahanya adalah bagaimana menumbuhkan agar orang peduli dengan kelompok buta aksara:

1). Teori empati atau ikut merasakan penderitaan orang lain sebagai penderitaan sendiri (Sarwono, 2002) perlu ditanamkan terutama pada masyarakat yang ekonominya cukup. Dalam empati, fokus usaha menolong terletak pada penderitaan orang lain, bukan pada penderitaan sendiri, karena dengan terbebasnya orang lain dari penderitaan itulah, si penolong akan terbebas dari penderitaanya sendiri (Miller, dalam Sarwono, 2002).

2). Teori norma masyarakat dikatakan bahwa orang menolong diharuskan oleh norma-norma masyarakat. Dalam kaitannya menolong kaum lemah, berlaku norma tanggungjawab sosial (social responsibility norm). Intinya bahwa kita wajib menolong orang lain tanpa mengharapkan balasan apapun di masa depan orang lain (Sarwono, 2002).

3). Norma keseimbangan. Berlaku bagi dunia Timur. Intinya bahwa seluruh alam semesta harus ada dalam keadaan seimbang, serasi dan selaras. Manusia harus membantu untuk mempertahankan keseimbangan itu, 
antara lain dalam perilaku menolong. (Sarwono, 2002).

Nilai-nilai empati, tanggungjawab sosial, atau norma keseimbangan perlu dikembangkan terhadap orang miskin terutama kelompok buta aksara dalam membantu program pemerintah memberantas buta aksara ini.

\section{c. Paradigma Humanistik}

Kelompok buta aksaran sebagian besar adalah usia dewasa atau usia produktif. Belajar orang dewasa tentu saja berbeda dengan belajar anak-anak. Belajar orang dewasa lebih cocok menggunakan paradigma humanistik. Paradikma ini dalam teori belajar orang dewasa dikembangkan oleh Rogers (1961), Maslow (1970), Allport (1985) dan banyak ditemukan dalam tulisan Knowles (1984). Paradigma humanis memandang bahwa orang dewasa dalam belajar memiliki kebutuhan yang spesifik serta kaya pengalaman yang dapat dijadikan sebagai sumber belajar.

Prinsip belajar orang dewasa menurut Gibb (dalam Brookfield, 1986) adalah bahwa: (1) pembelajaran harus berorientasi pada masalah (problem oriented), (2) pembelajaran harus berorientasi pada pengalaman sendiri warga belajar (exsperiences oriented), (3) pengalaman harus penuh makna (meaningfull) bagi peserta, pembelajar bebas untuk belajar sesuai dengan pengalamannya, (5) tujuan belajar harus ditentukan dan disetujui oleh warga belajar melalui kelompok belajar, dan (6) pembelajar harus memperoleh umpan balik tentang pencapaian tujuan.

Pendidikan keaksaraan bagi orang dewasa ini akan berhasil jika memperhatikan prinsip pendidikan orang dewasa tadi. Materi pendidikan tidak hanya belajar membaca menulis dan berhitung, tetapi materi yang bisa memecahkan kehidupan kesehariannya. Kebutuhan mereka intinya 
adalah memenuhi kebutuhan primer. Oleh karena itu materi pelajaran yang bisa membawa mereka ke arah sana dan bisa langsung diterapkan dalam kehidupan kesehariannya. Begitupun dari aspek metode mengajar juga meggunakan partisipatif, dengan melibatkan mereka secara aktif dalam pembelajaran.

Kelompok buta aksara sebagain besar berada di pedesaan dan daerah terpencil. Umumnya mata pencaharian mereka adalah bertani atau nelayan.. Oleh karena itu tujuan, materi metode, atau media pendidikan perlu memperhatikan kebutuhan mereka sebagai petani dan nelayan.

\section{d. Kebijakan Pemerintah}

Aspek penting yang menetukan dalam penyuluhan keaksaraan adalah political will dari pemerintah. Selama ini kecenderungan kelompok buta aksara adalah kelompok marginal. Mereka menempati daerah pedesaan, terpencil, dan sulit transportasi. Di sisi lain ketidakberdayan ekonomi dan fasilitas hidup lainnya menambah penderitaan mereka. Begitu pula di daerah perkotaan mereka menempati daerah-daerah pinggiran yang kumuh. Kelompok ini untuk bisa bangkit sungguh diperlukan polical will pemerintah, kebijakan yang berpihak kepada mereka.

\section{SIMPULAN DAN SARAN}

\section{Simpulan}

Hakekat pendidikan adalah upaya mengubah perilaku manusia dari perilaku lama yang tidak sesuai dengan tuntutan kebutuhan hidupnya dan menggantikannya dengan perilaku yang lebih baik. Untuk memahami perilaku ini dibutuhkan ilmu psikologi sosial dalam menjelaskan perilaku individu dan konteks sosial.

Secara umum buta aksara disebabkan oleh faktor struktural 
dan non struktural. Faktor struktural ini disebabkan oleh lingkungan dan budaya. Sedangkan faktor non struktural adalah berhubungan dengan kemiskinan, putus sekolah, keterbatasan sarana prasarana, dan kebijakan pemerintah yang kurang berpihak pada mereka.

Karakteritik kelompok buta aksara adalah usia dewasa, miskin, umumnya petani dan nelayan, umumnya jenis kelamin perempuan, hidup di daerah pedesaan dan terpencil, sedangkan bagi daerah perkotaan berada di pinggiran yang kumuh.

Dalam konteks psikologi sosial, upaya pendidikan keaksaraan tidak cukup orang diajak untuk belajar membaca, menulis dan berhitung. Pendidikan ini perlu dilakukan secara terpadu yang mengakomodarsikan semua faktor penyebab dan instansi terkait. Dimulai dengan membangun motivasi, persepsi, sikap, hingga perilakunya. Sikap empati dan solidaritas sosial juga diperlukan khususnya terhadap kelompk buta aksara. Sedangkan strategi pendidikan menggunakan paradigma humanistik.

\section{Saran}

Para pendidik khususnya dalam pendidikan keaksaraan perlu memahami psikologi sosial, dalam menjelaskan perilaku individu dan konteks sosial.

Pendidikan keaksaraan tidak hanya dilakukan dalam kontek belajar membaca, menulis dan berhitung tetapi perlu dilakukan secara terpadu. Dimulai dengan membangkitkan motivasi kelompok buta aksara, melalui materi pendidikan yang bisa meningkatkan taraf hidupnya (kebutuhan primer). Dengan cara ini diharapkan dapat mengubah persepsi, motif, sikap, dan perilakunya akan pentingnya kemampuan keaksaraan. 
Mereka perlu dibekali ilmu pengetahuan, sikap, dan keterampilan dalam berbisnis. Di sini barangkali tidak cukup hanya dengan memberikan keterampilan tertentu, apalagi keterampilan itu sederhana yang sulit bersaing. Mereka juga dibekali dengan manajemen usaha, manajemen pemasaran hasil produksi, termasuk pendampingan usaha dengan melibatkan pengusaha swasta. Di sinilah masalah perlunya ditanamkan tolong menolong antar sesama manusia. Nilai-nilai empati, tanggungjawab sosial, atau norma keseimbangan sebagai warga negara perlu dikembangkan terhadap orang miskin terutama kelompok buta aksara.

Mengingat kompleknya penyebab buta aksara, pendidikan keaksaraan diperlukan keberpihakan kebijakan pemerintah baik pusat maupun daerah. Strategi pendidikan menekankan pada pendidikan orang dewasa, dengan paradikma belajar humanistik. Oleh karena itu pendidikan keaksaraan perlu ditangani secara terpadu dengan melibatkan pihak terkait.

\section{DAFTAR PUSTAKA}

Arief Z. (1994). Studi Mengenai Tingkat Keaksaraan Fungsional di Beberapa Propinsi di Indonesia. Jakarta: Direktorat Pendidikan Masyarakat.

Ahmadi, Abu. (1991). Psikologi Sosial, edisi Revisi. Jakarta: Rineka Cipta.

Beal, GM., JM. Bohlen, dan JN. Raudabaugh. 1977. Leadership and Dynamic Action, Ames: lowa State University Press

Biro Pusat Statistik. (2004). Jumlah dan presentase Penduduk Buta Huruf Per Kecamatan. Jakarta: BPS

Dahlan, Alwi. (1997). Pemerataan Informasi, Komunikasi dan Pembangunan. Pidato Pengukuhan Guru Besar Ilmu Komunikasi FISIP UI. Jakarta.

Faturochman. (1996). Pengantar Psikologi Sosial. Yogyakarta: Pustaka. Kusnadi, dkk (2005). Pendidikan keaksaraan; Filosofi, Strategi, 
Implementasi; Jakarta: Depdiknas.

Knowles, MS. (1984). Andragogy in Action: Appliying Modern Principles of Adult Learning. San Francisco: Jossey-Bass Publishers.

Littlejohn, SW. (1996), Theories of Human Communication. Wadsworth, Publishing Company. An International Thomson Publishing Company.

Napitupulu, WP. (1999). Pengembangan dan Pelembagaan Pendidikan Luar Sekolah (PLS) dalam Mencerdaskan Kehidupan Bangsa. Makahal Seminar Sehari Pembangunan PLS memasuki Milenium Ketiga dalam rangka peringatan HAI ke-32 tahun 1999, Jakarta: Dikmas, Depdiknas

Sarwono. Sarlito Wirawan. (2002). Psikologi Sosial; Individu dan Teoriteori Psikologi Sosial. Jakarta: Balai Pustaka. , (2005). Psikologi Sosial; Psikologi Kelompok dan Psikologi Terapan. Jakarta: Balai Pustaka.

Unesco. (1980). Literacy 1972 - 1976. Progress Achieved in Literacy Throughout The World. Paris: Unecso Publishing.

Vir, Dharm. (1993). Psikologi Orang Dewasa dan Metode Pendidikan. Jakarta: Departemen Koperasi. 